\title{
Iliocaval Fistula - A rare Option for Permanent Vascular Access
}

\author{
Roman E. Kalinin, $\mathrm{PhD}, \mathrm{ScD}^{1}$; Igor A. Suchkov, $\mathrm{PhD}, \mathrm{ScD}^{1}$; Nina D. Mzhavanadze, $\mathrm{PhD}^{1}$; \\ Andrey A. Egorov, $\mathrm{PhD}^{1}$; Vladimir A. Yudin, $\mathrm{PhD}, \mathrm{ScD}^{1}$; Andrey V. Budnevsky, $\mathrm{PhD}, \mathrm{ScD}^{2^{*}}$; \\ Aleksandr I. Zhdanov, $\mathrm{PhD}, \mathrm{ScD}^{2}$; Sergey A. Kovalev, $\mathrm{PhD}, \mathrm{ScD}^{2}$; Dmitry V. Griaznov, $\mathrm{PhD}^{2}$; \\ Aleksandr N. Kinshov ${ }^{2}$ \\ ${ }^{1}$ Ryazan State Medical University, Ryazan, the Russian Federation \\ ${ }^{2}$ Voronezh N.N. Burdenko State Medical University \\ Voronezh, the Russian Federation
}

\begin{abstract}
The number of patients receiving maintenance dialysis treatment has been growing in recent years. Unfortunately, the lifetime of permanent vascular access is not unlimited, and some patients initially have problems with its formation. Because of these problems, there is a need to develop new methods of forming constant vascular access in this cohort of patients. This case shows the successful surgical approach to forming permanent vascular access in patients who are intravenous drug users and who have post-thrombotic syndrome of most veins, making them unsuitable for creating an arteriovenous fistula. (International Journal of Biomedicine. 2020;10(1):79-81.)
\end{abstract}

Key Words: permanent vascular access $\bullet$ haemodialysis $\bullet$ continuous ambulatory peritoneal dialysis

\section{Introduction}

The number of patients receiving maintenance dialysis treatment has been growing in recent years. ${ }^{(1,2)}$ The quality of this procedure is constantly improving; this fact has a positive effect on the life expectancy of patients receiving the procedure. $^{(3,4)}$ Different regimens of antithrombotic therapy are used widely in different algorithms of thrombosis and embolism prophylaxis and in various options for perioperative therapy in surgical treatment of vascular pathology, such as reconstructive surgery for atherosclerosis, phlebological manipulations, and others. In spite of this fact, anticoagulants are not widely used for haemodialysis (HD) patients with permanent vascular access (PVA)..$^{(5-7)}$ Unfortunately, the lifetime of PVA is not unlimited, and some patients initially have problems with its formation. ${ }^{(8-10)}$ Because of these problems, there is a need to develop new methods of forming constant vascular access in this cohort of patients. We present

*Corresponding author: Prof. Andrey V. Budnevsky, PhD, ScD. Professor of the Department of Internal Medicine, Voronezh N.N. Burdenko State Medical University. Voronezh, the Russian Federation.E-mail: budnev@list.ru our approach to surgical treatment of a patient with severe renal failure. ${ }^{(11-15)}$

\section{Case Presentation}

A 54-year-old white male, intravenous drug user, has received continuous ambulatory peritoneal dialysis (CAPD) for two years. This type of renal replacement therapy was chosen because the patient's veins (deep and superficial, both on the upper and lower extremities) were unsuitable for the formation of permanent vascular access due to persistent obliteration. During the last 12 months, the patient has undergone four episodes of St. Aureus and E. Coli peritonitis. As a result, use of CAPD became inadequate due to a dramatic decrease in peritoneum resorption capabilities.

In such circumstances, patients are usually transferred to HD. When making a decision about the formation of a PVA, we encountered the following issues: ultrasound signs of postthrombotic syndrome of jugular, subclavian and iliac veins, and of deep and superficial veins of the upper and lower extremities from both sides. An extensive network of collaterals with a maximum diameter of $3 \mathrm{~mm}$ was present across all segments, but they were absolutely unsuitable for forming a 
PVA. The left common iliac vein (CIV) and the inferior vena cava (IVC) were found to be intact, suitable both for catheterization and surgery. We decided to create a PVA using a VENAFLO ${ }^{2} 2$ ePTFE straight vascular graft $6 \mathrm{~mm} \times 50 \mathrm{~cm}$. Before surgery, the dialysis solution was drained from the abdominal cavity. Epidural anaesthesia was used. An extraperitoneal approach to the left CIV was used. Its length was $3 \mathrm{~cm}$, which was not enough for clamping and implanting a vascular prosthesis. The iliac arteries, the lower part of the abdominal aorta and the IVC were mobilized. An end-to-side anastomosis was created between the lower part of the IVC involving the beginning of the left CIV and the vascular graft. Another part of the vascular graft was moved down under the skin of the left thigh, and the second anastomosis was performed between the end of the vascular graft and the side of the left external iliac artery.

The stages of the intervention are presented in Figures 1,2 , and 3 .

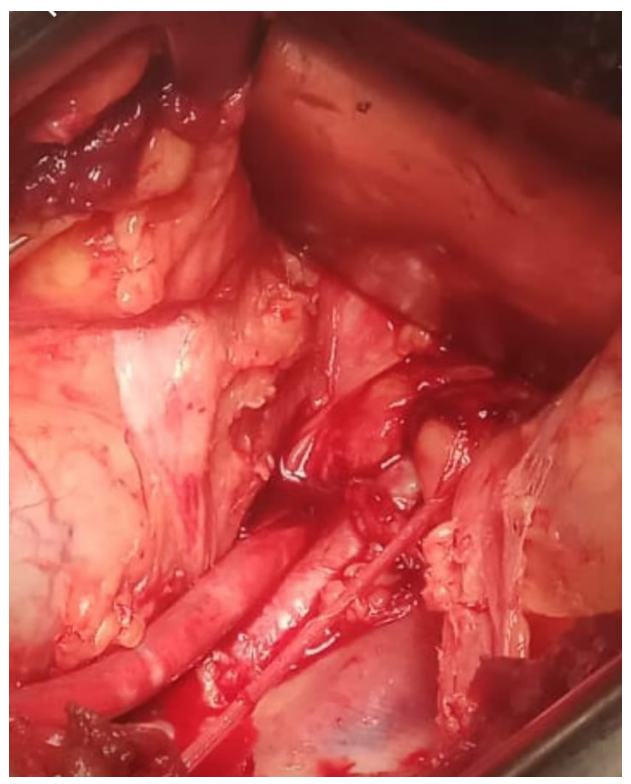

Fig. 1. The inferior vena cava.



Fig. 2. The synthetic vascular prosthesis on the front surface of left thigh.

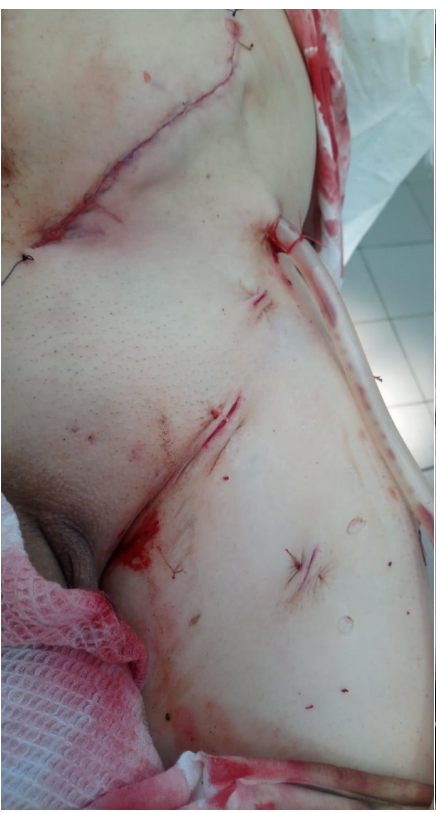

Fig 3. The view of postoperative wounds.

Two hours after the operation, the patient was moved to the cath lab, and a double-lumen catheter was implanted into the right superficial femoral artery.

Three hours after this procedure, the patient underwent the first HD session using this catheter. Figure 4 shows HD using a femoral artery catheter.

The HD session lasted 3 hours; ultrafiltration of 2,000 $\mathrm{ml}$ was completed. The next day, the duration of dialysis was the same, and the volume of ultrafiltration was $2,500 \mathrm{ml}$. A transfusion of $400 \mathrm{ml}$ of red blood cells was added. The patient received antibiotic and anti-inflammatory therapy. HD was performed every second day for 2 weeks. That was followed by three sessions of HD using the access with the punction of vascular graft, then the catheters were surgically removed from the femoral artery and abdominal cavity. On the 17th day, the patient was discharged for outpatient treatment with programmed $\mathrm{HD}$.

The search for new solutions to the problem of PVA formation in patients for whom standard methods cannot be used is extremely relevant and is carried out by many surgical scientists. Our proposed method allows HD in a patient with persistent vascular obliteration. This case shows the successful surgical approach to forming permanent vascular access in patients who are intravenous drug users and who have postthrombotic syndrome of most veins, making them unsuitable for creating an arteriovenous fistula.

\section{Competing Interests} interests.

The authors declare that they have no competing

\section{Disclaimers}

The opinions expressed in this article are the authors' own and do not reflect the view of the institutions or funder. 


\section{References}

1. NKF-DOQI clinical practice guidelines for vascular access. National Kidney Foundation-Dialysis Outcomes Quality Initiative. Am J Kidney Dis. 1997;30(4 Suppl 3):S150-91.

2. Akoh JA, Hakim NS. Preserving function and longterm patency of dialysis access. Ann R Coll Surg Engl. 1999;81(5):339-42.

3. Gonzalez E, Bajo MA, Carrero JJ, Lindholm B, Grande $\mathrm{C}$, Sánchez-Villanueva $\mathrm{R}$, et al. An increase of plasma advanced oxidation protein products levels is associated with cardiovascular risk in incident peritoneal dialysis patients: a pilot study. Oxid Med Cell Longev. 2015;2015:219569. doi: $10.1155 / 2015 / 219569$

4. Kudasov AB, Starosel'tsev SL. [Continuous ambulant peritoneal dialysis as the primary method for treating terminal chronic kidney failure]. I.P. Pavlov Russ Med Biol Herald. 2006;(3):71-4. [Article in Russian].

5. Kalinin RE, Suchkov IA, Pshennikov AS, Agapov AB. [Evaluation of efficacy and safety of different types of anticoagulant therapy in venous thrombosis]. Novosti Khirurgii. 2015;23(4):416-23.doi:10.18484/2305-0047.2015.4.416. [Article in Russian].

6. Agapov AB, Suchkov IA, Ryabkov AN. [Direct oral anticoagulants in patients with deep venous thrombosis of lower extremities]. Science of the young (Eruditio Juvenium). 2016; 4(2):147-57. [Article in Russian].

7. Oleśkowska-Florek W, Połubinska A, Baum E, Matecka M, Pyda M, Pawlaczyk K, et al. Hemodialysis-induced changes in the blood composition affect function of the endothelium. Hemodial Int. 2014;18(3):650-6. doi: 10.1111/hdi.12148.

8. Murphy GJ, White SA, Knight AJ, Doughman T,
Nicholson ML. Long term results of artenovenous fistulas using transposed autologous basilic vein. $\mathrm{Br} \mathrm{J}$ Surg. 2000;87(6):819-23. doi:10.1046/j.1365-2168.2000.01435.x

9. Gottmann U, Sadick M, Kleinhuber K, Benck U, Huck K, Krämer BK, Birck R. Central vein stenosis in a dialysis patient: a case report. J Med Case Rep. 2012;6:189. doi: 10.1186/1752-1947-6-189.

10. Kalinin RE, Suchkov IA, Egorov AA, Nikulina NN. [Endothelial dysfunction in program hemodialysis-dependent patients]. Science of the Young (Eruditio Juvenium). 2019;7(1):79-85. doi:10.23888/HMJ20197179-85. [Article in Russian].

11. Moisiuk IaG, Beliaev AIu. Permanent vascular access for hemodialysis. Moscow; 2004. [In Russian].

12. Kalinin RE, Suchkov IA, Egorov AA. [Possibilities of roentgen-endovascular and hybrid correction of permanent vascular access in dialysis-dependent patients]. Science of the Young (Eruditio Juvenium). 2018;6(4):561-8. doi:10.23888/ HMJ2018 64561-568. [Article in Russian].

13. Kalinin RE, Suchkov IA, Egorov AA, Medvedeva OV. [Examples of non-standard reconstructions in hemodialysis patients with permanent vascular access]. Novosti Khirurgii. 2017;25(1):87-92.doi:10.18484/2305-0047.2017.1.87. [Article in Russian].

14. Kalinin RE, Suchkov IA, Egorov AA. [Brachiojugular shunting provides permanent vascular access in occlusion of subclavian veins]. Science of the Young (Eruditio Juvenium). 2017;5(3):428-34. [Article in Russian].

15. Kalinin RE, Suchkov IA, Egorov AA. [Case of non-standard reconstruction of arteriovenous fistula for hemodialysis]. Avicenna Bulletin. 2016;20(2):53-5. doi:10.25005/2074-0581-2016-18-2. [Article in Russian]. 